\title{
An Exploration of the Knowledge Components of Spiritual Health Based on the Quran and Hadiths: A Qualitative Research
}

\author{
Mohammad Sanagoei Zadeh, Mehdi Mesri*, Seyed Morteza Hosseini, Hossein Shamsi Gooshki \\ and Majid Ahmadi \\ Medicine, Quran and Hadith Research Center, Baqiyatallah University of Medical Sciences, \\ Tehran, Iran; hossein.shams64@yahoo.com
}

\begin{abstract}
Spiritual health is one dimension of human health, but the concept and its components are still a subject of discussion. The purpose of this study was to identify the components of spiritual well-being based on the Quran and hadiths. This was a qualitative study conducted as thematic analysis. Qualitative data were extracted by studying the Quran and hadiths, and then coded and categorized. The categories were re-examined and refined, and the main themes were discovered afterward. The findings of this study showed that spiritual well-being has cognitive, emotional and behavioral levels with the four components of patience, certainty, justice and jihad, while spiritual illness entails doubt, impatience, oppression and weakness. In the processes of achieving spiritual health, each component undergoes the stages of self-awareness, God's knowledge, certainty of heart, and attachment to God. By contrast, in the process of the formation of each component, there is a spiritual illness that includes ignorance of self or God, doubt, and attachment to non-God. The results of the current study are useful for evaluating spiritual health and planning for education in order to enhance spiritual well-being and elaborating an Islam-based spiritual health pattern.
\end{abstract}

Keyword: Hadiths, Health Knowledge, Qualitative Research, Quran, Spiritual Health

\section{Introduction}

The term "spiritual well-being", first laid out in 1971 by David O'Moberg, has been defined in two vertical and horizontal dimensions ${ }^{1}$. The vertical dimension refers to communication with God, and the horizontal dimension indicates a sense of purposefulness and satisfaction in life, regardless of any specific religion $\stackrel{1}{*}$. Some studies have introduced other models for spiritual health including the Ellison Model ${ }^{2}$, the Woods model ${ }^{3}$, the four-dimensional Ross model ${ }^{4}$, and Fisher's Four Domains Model ${ }^{5}$. All of these models are based on communicating with a being beyond man, which conveys a sense of connection with a superior and holy creature in order to achieve a meaningful life on individual, social and personal levels.
Spirituality is recognized to be a dimension of people's health as defined by the World Health Organization (WHO) ${ }^{6}$. Spirituality is a way of life resulting from awareness of dimensions pertaining to the future and characterized by distinct values, especially in relation to oneself, others, nature, life, and everything else, including God or a superior power ${ }^{?}$.

Spirituality and religious faith are two separate concepts ${ }^{6}$. Secular spirituality is an aspect of human life and experience without believing in religion. This may be useful or even necessary for the spiritual exercises of human beings, such as meditation or concentration of senses, but it does not involve believing in supernatural explanations. The features of secular spirituality are: the spirit of escape and sentimentality, eccentricity, creation 
of a spiritual path by searching for existing options, and constantly changing them with the aim to avoid punishment and find fresh options ${ }^{\frac{6.8}{.}}$.

Spirituality in its religious sense is considered as a transcultural experience derived from religion and has been described as a sort of human relationship with God. Thus, religious spirituality based on worshipping God and theological teachings is a recognition of the purpose of creation and life, as well as an effort to achieve spiritual evolution and self-fulfillment $\frac{6,9}{}$.

Islam is considered as a comprehensive faith and the official religion of the Iranian community. Muslims comprise about one-fifth of the world's population, accounting for over one billion people around the world. This population is scattered in almost 50 countries and regions across Asia and Africa. Diversity of races and languages and religious conservatism can be seen in these countries, and the governments may be Islamic or secular ${ }^{10}$. Thus, identification of a form of spiritual health in accordance with the views of Islam is important. According to the hadith of "al-Thaqalayn", the Quran and "Ahl al-Bayt" are two integral legacies of Prophet Muhammad that provide the fundamental truth of Islam ${ }^{11}$. Hence, the focus of this study was on spiritual health based on the Quran and hadiths.

The term "spiritual health" does not appear in the Quran and hadiths, but some studies have extracted similar words, for instance "the healthy heart" (QalbSalim), which comes from a Quranic verse ${ }^{a}$ (26:89) $\frac{12}{2}$. The perfect human has been endowed with a common heart $\frac{13,14}{\text {, which }}$ is a dimension of the soul and home to perceptions and emotions, documented in the Quran through concepts such as health, illness and mortality ${ }^{13}$. Having a sound heart means having a calm spirit as well as hope and love, security and happiness, all achieved through faith and piety. Humans are capable of purging their heart through establishing a relationship with God and reforming the outside world ${ }^{14}$. Other studies have mentioned "Hayat Tayyeb" as a term close to spiritual well-being (Holy Quran, 16:97). A person who lives in "Hayat Tayyeb" is free from everything and sees life and all events in a divine light. Therefore, a person who lives in "Hayat Tayyeb" has a permanent server and dignity $\frac{15}{}$.

Assessment of spiritual health depends on access to the components of spiritual well-being. Therefore, the

${ }^{a}$ Haleem MA, editor. The Quran,OUP Oxford. present research aimed to identify these components based on the Quran and hadiths.

\section{Methods}

Based on the aim of the research, the statistical population of the study comprised of Islamic resources including the Quran in Arabic and the hadiths in Usūl al-Kāfî̀ ${ }^{b}$, Bihhār al-Anwār ${ }^{c}$, Nahj al-Balagha ${ }^{\mathrm{d}}$, and Al-Sahifa al-Sajjadiyya ${ }^{e}$ (in Arabic). The research was conducted according to Shiite views. Since the Quran and hadiths are not focused on spiritual health, Islamic philosophers and commentators have not discussed this subject, which demonstrates the difficulty of studying the topic. Therefore, in order to analyze the logic behind these texts, categorize them and achieve rich and detailed data, thematic analysis was used, which is a qualitative method 16 .

The present study used purposive sampling, done through the adequacy of data and saturation of the categories. The research steps were carried out as follows:

\subsection{Familiarization with the Data}

The purpose of this phase was to extract data, read and reread the data, and note initial ideas. For this purpose, the following steps were taken: a) searching for the word "health" in the Quran and hadiths; b) searching for words opposite to "health" such as "sadness", "fear", "illness" in the Quran and hadiths; $\mathbf{c}$ ) reading and rereading the data collected by the researcher and his colleagues; and d) refining these codes by focusing on the relationship between man and God as the superior creature.

\subsection{Generating the Initial Codes}

At this stage, the objective was a systematic coding of the data based on the interesting features across the entire data set and collecting relevant data regarding each code. Therefore, in this phase, coded data included verses and hadiths extracted by the researcher and their colleagues.

\footnotetext{
' Kulaynī, M.Al-Kāfì, Téhéran: Dār al-Kutub al-Islāmīyya

'Majlisi, M. Biḥār al-Anwār: Bayrut: Alwfa' institute

¿Sharīfal-Raḍi, Muhammadibnal-Husayn, NahjulBalagha = Peak of Eloquence: Sermons, Letters, and Sayings of Imam Ali Ibn Abu Talib. Bombay :ImamFoundation

${ }^{\mathrm{e}}$ Chittick WC. The Psalms of Islam: Muhammadi Trust of Great Britain a. Nothern Ireland
} 


\subsection{Searching for Themes}

In this phase, the purpose was to reach themes by collecting codes and to gather all data relevant to each potential theme. On the other hand, by reading, rereading and refining those codes, we were able to discover the relationship between the codes and potential themes.

\subsection{Reviewing Themes}

At this point we checked the themes and refined the results through integrated themes, and subsequently generated a thematic table of the analysis.

\subsection{Defining and Naming Themes}

In this phase, themes were explained and the relationships between them were determined. The results were then presented to three experts to confirm validity. The experts were: an oncologist, a $\mathrm{PhD}$ in Quran and Islamic resources, and an expert in hadiths. All of them were

Table 1. Themes, categories and subcategories faculty members and had degrees as associate professors and assistant professors, in addition to experience about spiritual health.

\subsection{Preparing the Report}

The following actions were taken at this stage: a) final analysis of selected extracts; b) relating the research findings to the research question; and c) generating literature and producing a report.

\section{Results}

The results of the study demonstrated that there are three themes on the subject of spiritual health: 1. levels of spiritual health, 2 . components of spiritual health, and 3. the process of the formation of spiritual health. Each theme was characterized by specifications as presented in (Table 1).

\begin{tabular}{|c|c|c|}
\hline Themes & Categories & Subcategories \\
\hline \multirow[t]{3}{*}{$\begin{array}{l}\text { Levels of Spiritual } \\
\text { Health }\end{array}$} & Cognition & $\begin{array}{l}\text { 1. Belief in the divine power (God is ghader) } \\
\text { 2. Faith in the divine knowledge (God is aalem) } \\
\text { 3. Faith in the divine mercy (rahmat) } \\
\text { 4. Faith in Allah's mercifulness and compassion (God is } \\
\text { rahman and rahim) } \\
\text { 5. Belief in the truth of the divine promise (God is sadegh) } \\
\text { 6. Faith that Allah is independent of all (God is samad) } \\
\text { 7. Belief in Allah as the provider (God is razzagh) } \\
\text { 8. Faith that Allah will inflict severe punishment on those who } \\
\text { deserve it (oghoobat) } \\
\text { 9. Belief in the divine justice (edalat) } \\
\text { 10. Faith in the divine gratitude (God is shakoor) } \\
\text { 11. Faith that Allah will resurrect those in the graves (God is } \\
\text { mohyee al amvaat) } \\
\text { 12. Faith in humans returning to Allah (ma'aad) } \\
\text { 13. Faith in the divine care and protection (malja') } \\
\text { 14. Faith in Allah as the guardian of the believers (velayat) } \\
\text { 15. Faith in Allah as the judge of all humans (zalghazaa) } \\
\text { 16. Faith that Allah hears the pleadings of humans (God is } \\
\text { same') } \\
\text { 17. Belief in the divine wisdom (hekmat) }\end{array}$ \\
\hline & Emotion & $\begin{array}{l}\text { 1. Surrender to Allah (taslim) } \\
\text { 2. Entrusting affairs to Allah (tafviz) } \\
\text { 3. Trusting in Allah (tavakkol) } \\
\text { 4. Acceptance of the divine justice (reza) }\end{array}$ \\
\hline & Behavior & $\begin{array}{l}\text { 1. Kindness (otoofat) } \\
\text { 2. Endurance in the path of obedience to Allah (esteghaamat) } \\
\text { 3. Praying (salaat) } \\
\text { 4. Charity (sadagheh) }\end{array}$ \\
\hline
\end{tabular}




\begin{tabular}{|c|c|c|}
\hline Themes & Categories & Subcategories \\
\hline $\begin{array}{l}\text { Levels of Spiritual } \\
\text { Health }\end{array}$ & Behavior & $\begin{array}{l}\text { 5. Jihad for Allah } \\
\text { 6. Paying (zakaat) } \\
\text { 7. Patience (sabr) } \\
\text { 8. Fulfilling promises (mofi al ahd) }\end{array}$ \\
\hline \multirow[t]{4}{*}{$\begin{array}{l}\text { Components of } \\
\text { Spiritual Health }\end{array}$} & Certainty (Yaghin) & $\begin{array}{l}\text { 1. Being alert (khabir) } \\
\text { 2. Belief in the divine wisdom (hekmat). } \\
\text { 3. Learning from previous mistakes (ebrat) } \\
\text { 4. Knowing about the traditions (sonnat) }\end{array}$ \\
\hline & Patience (Sabr) & $\begin{array}{l}\text { 1. Seeking heaven (bashir) } \\
\text { 2. Fearing hell (nazir) } \\
\text { 3. Detachment from the world (zohd) } \\
\text { 4. Willingness to die in the path of obedience to Allah } \\
\text { (taraghob) }\end{array}$ \\
\hline & Justice (Adl)» & $\begin{array}{l}\text { 1. Having a deep understanding (fahim) } \\
\text { 2. Showing acceptance of judgment (hasib) } \\
\text { 3. Exercising endurance (sabbar) }\end{array}$ \\
\hline & Jihad & $\begin{array}{l}\text { 1. Enjoining what is right (amr be ma'rouf) } \\
\text { 2. Forbidding what is wrong (nahyazmonkar) } \\
\text { 3. Stability in actions (sabet) } \\
\text { 4. Hostility towards the corrupt (ghaher) }\end{array}$ \\
\hline \multirow[t]{4}{*}{$\begin{array}{l}\text { The Process of } \\
\text { the Formation of } \\
\text { Spiritual Health }\end{array}$} & Self-Consciousness & $\begin{array}{l}\text { 1. Awareness of one's shortcomings (khashe') } \\
\text { 2. Modesty (tavazo') } \\
\text { 3. Awareness of God (towhid) } \\
\text { 4. Declaring one's inferiority to God (khaze') } \\
\text { 5. Lack of awareness of the expediency of one's affairs (ghasir) }\end{array}$ \\
\hline & $\begin{array}{l}\text { God- } \\
\text { Consciousness }\end{array}$ & $\begin{array}{l}\text { 1. Awareness of the divine attributes (Asma al Hosna) } \\
\text { 2. Attention to the divine power and grace when pleading } \\
\text { with God (vahhab) } \\
\text { 3. Reminding oneself of the divine blessings (na'eem) } \\
\text { 4. Awareness of God answering prayers (mojib) }\end{array}$ \\
\hline & Certainty & $\begin{array}{l}\text { 1. Trust in the divine wisdom (hekmat) } \\
\text { 2. Faith in God as protector of human life (hafiz) }\end{array}$ \\
\hline & Belonging to God & $\begin{array}{l}\text { 1. Praying (salaat and do'aa) } \\
\text { 2. Seeking the divine forgiveness (ghafer) } \\
\text { 3. Acknowledging the divine bounties (God is mon'em) } \\
\text { 4. Satisfaction with God's will (ghane') } \\
\text { 5. Finding refuge in God (tavakkol) }\end{array}$ \\
\hline
\end{tabular}

\subsection{Spiritual Health Levels}

There are three levels of spiritual health including cognitive, emotional and behavioral levels.

\subsubsection{The Cognitive Level}

This level comprises beliefs and knowledge related to God and the divine attributes. In this regard, seventeen subcategories were obtained. The cognitive level of spiritual health refers to knowledge of God and His attributes as mentioned in the Quran and also confirmed by hadiths. As stated in one narrative ${ }^{\mathrm{f}}$ attributed to Imam Sadegh, "Faith has different degrees.... As the emperor of the human body, the heart is responsible for the decisions, prohibitions, and rebellions of the members, and since man thinks and understands through the heart, its role is confession and knowledge" $\stackrel{17}{ }$.

\subsubsection{The Emotional Level}

The extracted categories indicated that this level was higher than the previous one. A person, who has spiritual

${ }_{\mathrm{f}}^{\mathrm{f}}$ Kulaini S. Usūl al-Kāfī (in Arabic). Dar-ol-Kotob-al-Eslamiah, Tehran, $v 2, p 35$. 
health trusts in God, surrenders to His will, entrusts affairs to Him, and makes satisfies for the divine justice. Imam Ali said, "Faith has four pillars, including faith in God, entrusting affairs to Him, righteousness in surrendering to God, and submission to His will" 117 . Imam Sadegh also said, "Faith in the heart means consent and submission to monotheism and the mission of the Prophet, Islam and the Holy Book" $\mathrm{h} 17$.

\subsubsection{The Behavioral Level}

This category pertains to the fact that faith at this level can appear in all parts of the human body, and the person who shows this level of spiritual well-being perpetrates righteous deeds. Righteousness is seen in acts performed for the sake of God. As quoted in Usūl al-Kāfī, Imam Sadegh said, "Faith is a confession of the language, transplantation in the heart, and an act by the body" $1 \underline{17}$.

\subsection{The Components of Spiritual Health}

Based on this category, the four components of patience, certainty, justice and jihad were extracted. According to Imam Ali:

"Faith (Iman) has four components, and each has its indicators. The first component is patience, with the indicators of seeking heaven, fearing hell, detachment from the world, and willingness to die in the path of obedience to Allah. The second component is certainty, and its indicators include being alert, belief in the divine wisdom, learning from previous mistakes, and knowing about the traditions. The third component is justice, and the indicators are a deep understanding, acceptance of judgment, and exercising endurance. The forth component is Jihad, with the indicators of enjoining what is right, forbidding what is wrong, stability in actions, and hostility towards the corrupt" $\mathrm{j} 17$.

The following components were extracted from the Quran:

\footnotetext{
${ }^{\mathrm{g}}$ Kulaini S. Usūl al-Kāfì (in Arabic). Dar-ol-Kotob-al-Eslamiah, Tehran, v 2, p 51.

${ }^{\mathrm{h}}$ Kulaini S. Usūl al-Kāfì (in Arabic). Dar-ol-Kotob-al-Eslamiah, Tehran, v 2, p 35.

${ }^{i}$ Kulaini S. Usūl al-Kāfī (in Arabic). Dar-ol-Kotob-al-Eslamiah, Tehran, $v 2, p 27$.

${ }^{j}$ Kulaini S. Usūl al-Kāfì (in Arabic). Dar-ol-Kotob-al-Eslamiah, Tehran., $v$ 2, p 51 .
}

1. Patience: "Moumenin are those who are steadfast and put their trust in the Lord" (29:59) 12 .

2. Certainty: "And worship the Lord until the certainty (death) comes to you"(15:99)12.

3. Justice: "You who believe, be steadfast in your devotion to God and bear witness impartially. Do not let the hatred of others lead you away from justice, but adhere to justice, for that is closer to awareness of God. Be mindful of God. God is well aware of all that you do" $(5: 8) \frac{12}{\text {. }}$.

4. Jihad: "Say [Prophet], 'I advise you to do one thing only: Stand before God, in pairs or singly, and think; there is no sign of madness in your companion [the Prophet] he is only warning you before severe suffering arrives" $(34: 46)^{12}$.

\subsection{The Process of the Formation of Spiritual Health}

Other themes were extracted by the coding and categorization of narratives, especially the prayers in Sahifa Sajjadiyah, including the "formation of spiritual health". This theme is comprised of self-consciousness, God-consciousness, certainty, and belonging to God.

\subsubsection{Self-Consciousness}

This code involves awareness of one's weaknesses and shortcomings against God, and includes the following:

- Awareness of one's shortcomings. Imam Sajjad writes in Sahifeh Sajjadiyeh, “... because I'm not the first one to accompany you with joy and you have been enthusiastic about him, although he was not entitled to it" (prayer 13) $\frac{18}{\text {. }}$

- Awareness of one's humble nature. Imam Sajjad says, "I rise in the morning and enter into the evening as Thy lowly slave. I make no profit or loss for myself except through Thee. I am witness to that and I confess to the frailty of my strength and the paucity of my stratagems. So accomplish what Thou hast promised me and complete for me what Thou hast given me, for I am Thy slave, miserable, abased, frail, distressed, vile, despised, poor, fearful, and seeking sanctuary" (prayer 21) 18 .

- Awareness of God. Imam Sajjad says, "And do not erase me from your memories of what you have given $m e^{\prime \prime}$ (prayer 21$)^{18}$. 
- Declaring one's inferiority to God. Imam Sajjad says, "My Lord, I am reading while I am the poor, miserable, abased, apprehensive, fearful, quaking, and poor" (prayer 54$)^{18}$.

- Lack of awareness of the expediency of one's affairs. Imam Sajjad says, "Who is more ignorant than me about his own doings?” (prayer16) $\frac{18}{\text {. }}$

\subsubsection{God-Consciousness}

This code refers to the fact that at this stage, man becomes aware of God. This awareness includes the following:

- Awareness of the divine attributes. Imam Sajjad says, "I came back, and said, 'How can my Lord depend on another needy creature? And why would the poor try to fulfill their needs through other poor beings?" (prayer 13) ${ }^{18}$.

- Awareness of the divine power and grace when asking the Lord for a favor Imam Sajjad says, "And I knew that if I asked You for help, even if it were too much, it would be very little compared to my tremendous wealth, and my extraordinary desire for divine worship is due to my limited abilities, and the circle of gravity will not suffer from the demands of anyone" (prayer 13) $\frac{18}{\text {. }}$

- Remembrance of the divine blessings. Imam Sajjad says, "[The Lord asks,] 'which of these two times is your praise more worthwhile? The time of health that made me happy with your clean days, and because of that, I have been glad to give you satisfaction and blessings, and because of that, I have been able to work well for me to succeed? Or the time of sickness?" (prayer 15), $\underline{18}$.

- Awareness of God answering prayers. Imam Sajjad says, "At Thy service! At Thy service! Thou hearest him who complains to Thee! Thou receivest him who has confidence in Thee! Thou savest him who holds fast to Thee! Thou givest relief to him who seeks shelter in Thee" (prayer 51) $)^{18}$.

\subsubsection{Certainty}

This theme is explained by the following two sub-categories:

- Faith in the divine wisdom. Humans have trusted the divine wisdom. In Sahifeh Sajjadiyeh, Imam Sajjad refers to God as "He whose wisdom cannot be altered by any means (prayer 13)" 1 .
- According to the Holy Quran, "They became more arrogant in the land, and intensified their plotting of evil - the plotting of evil only rebounds on those who plot. Do they expect anything but what happened to earlier people? You will never find any change in God's practice; you will never find any deviation there" (35:43) $\frac{12}{\text {. }}$.

- God is the guarantor of human life. Humans have believed that their life is guaranteed by God. Imam Sajjad writes in Sahifeh Sajjadiyeh, "Let Thy clear promise in Thy Revelation which Thou hast followed in Thy Book with Thy oath cut off our worry about the provision for which Thou hast made Thyself responsible and sever our occupation with everything whose sufficiency Thou hast guaranteed" (prayer 29) $\frac{18}{\text {. }}$

- To quote the Holy Quran: "There is not a creature that moves on earth whose provision is not His concern. He knows where it lives and its [final] resting place: it is all [there] in a clear record" $(11: 6)^{12}$.

\subsubsection{Belonging to God}

This theme is explained by the following sub-categories:

- Praying. Prayer represents the connection with God. The prayers of Imam Sajjad in Sahifeh Sajjadiyeh represent the human connection and relationship with God in all situations and circumstances. In the Holy Quran, it is said, "[Prophet, say to the nonbelievers] 'What are you to my Lord without your supplication? But since you have written off the truth as lies, the inevitable will happen" (25:77) 12 .

- The divine forgiveness. God is forgiving. Believing that God is the Creator and all the blessings are from God, and he does not forgive himself with the blessings, will make man belong to God. Imam Sajjad writes of God in Sahifeh Sajjadiyeh: "He who does not muddy His gifts by the imposition of obligations" (prayer 13). And according to Quran, "God is the Creator of all things; He has charge of everything." (39:62)12.

- Acknowledging the divine bounties. Humans thank God for all states of life, easy or troubled, and this is between man and God. Imam Sajjad said, "God, praise is Thine for the good health of 
my body which lets me move about, and for the ailments which Thou causest to arise in my flesh. For I know not, my Lord, which of the two states deserves my thanking Thee more, and which of the two times is more worthy of my praise. Is it the time of health, within which Thou makest me delighted in the agreeable sides of Thy provision, through which Thou givest me the joy to seek the means to Thy good pleasure and bounty, and by which Thou strengthenest me for the acts of obedience which Thou hast given me success to accomplish? Or is it the time of illness through which Thou puttest me to the test and bestowest upon me favors, the lightening of the offenses that weigh down my back, purification of the evil deeds into which I have plunged, incitement to reach for repentance, reminder of the erasure of misdeeds through ancient favors?" (prayer 15) $\frac{18}{\text {. }}$

- Satisfaction with and trust in the will of God, which shows the bond between man and the Creator. Imam Sajjad said, "Make me love what Thou hast approved for me and make it easy for $m e "$ (prayer15) 18 .

- Finding refuge in God. When man believes that he is alone, he will be connected with his God. This loneliness means that there is no other being than God to help him. Imam Sajjad said, "God suffices the isolated and the weak, and protects against terrifying affairs" (prayer 21) $\stackrel{18}{\text {. }}$

\section{Discussion}

The present study was a qualitative research using thematic analysis with the aim of identifying the knowledge components of spiritual well-being based on the verses of the Quran and hadiths. Based on the findings presented herein, spiritual well-being and spiritual illness are centered on religious faith. If a person has religious faith, he or she enjoys spiritual health, and those who do not will experience spiritual illness. Based on Quranic verses and hadiths, the knowledge components of spiritual health comprise three main themes: $\mathbf{1}$. the cognitive, emotional and behavioral levels; 2 . components; and $\mathbf{3}$. the process of the formation of spiritual health.

These themes can conceptualize spiritual well-being. The components of spiritual health including patience, certainty, justice and jihad exist at cognitive, emotional and behavioral levels. On the cognitive level certainty pertains to God and His attributes, on the emotional level it means submitting to God, and on the behavioral level it refers to obeying His commands. Performing actions is based on certainty, not doubt. Patience also has cognitive, emotional and behavioral levels. On the cognitive level, patience is believed to be a divine test. On the emotional level spiritual people adjust their feelings on the basis of patience, which means they hope to solve problems and trust in God, and on the behavioral level, they try to be patient, for instance by acting peacefully and not rushing matters. Justice also has three levels. At the cognitive level, spiritual people believe that God is not ruthless, at the emotional level, they experience pleasant feelings about God's righteousness and on the behavioral level, and they regulate their behavior based on the divine justice. In the component of Jihad, there are also three levels of spiritual well-being. The level of cognition pertains to the belief in fighting falsehood, followed by a feeling of satisfaction and happiness on the emotional level, and endeavoring at the behavioral level. As can be seen above, all four components of spiritual well-being have three levels. To realize each of these components in humans, the process of the formation of spiritual health should be formatted through the four stages of self-consciousness, God-consciousness, certainty, and belonging to God. To achieve spiritual health, it is essential to pass through all of these four stages (Figure 1).

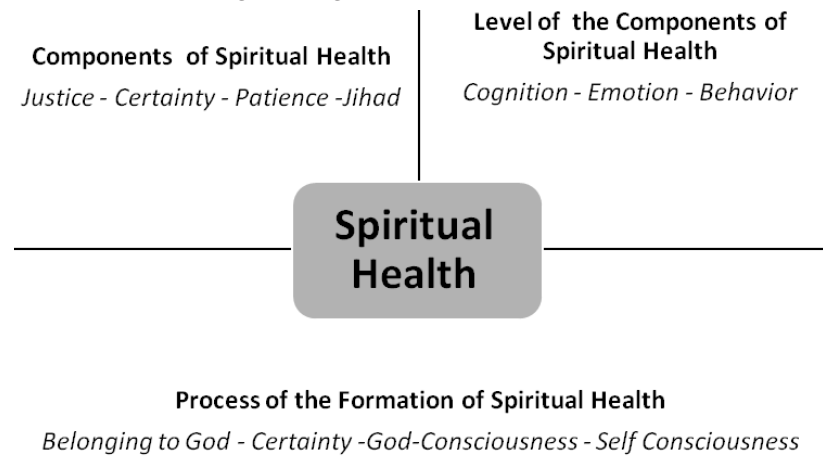

Figure 1. The relationship between the three themes.

A comparison between the findings of the present study and those of previous studies demonstrated that in Islamic teachings, spiritual health is the connection with God (a superior existence) $\frac{7,14,19,20}{2}$ and this connection is the ultimate goal of man. Spiritual people place all their actions in life in the divine path. According to Islamic teachings, people will fear and grieve if they are not connected with God. This assumption is based on many Quranic verses, for instance "Those who believe in Allah 
and do right shall not fear, nor will they grieve" (Quran, $6: 48 ; 9: 40)^{12}$. All spiritual health models have pointed to this notion ${ }^{2-5}$. The Ellison model states that spiritual health is comprised of religious and psycho-social components. While the religious component refers to the connection with God or a superior being, the psychosocial element denotes individuals' feelings about what they are, their actions and the reasons behind them, and where they belong 2 . These elements are similar to the two components of spiritual health in the present study, i.e., God-consciousness and self-consciousness.

According to the existing literature, the components of spiritual health are cognitive, emotional and behavioral ${ }^{21}$, and there are four domains in spiritual health including the relationship with God, oneself, the community and the environment ${ }^{22}$. Likewise, this research showed spiritual health to have three levels: cognitive, emotional and behavioral. The cognitive level refers to the insight into God, oneself and one's surroundings (others and the nature); the emotional component refers to one's attitude toward God, oneself, others and the nature; and the behavioral component pertains to one's actions in relation to God, oneself, others and the nature. Therefore, this study could form a link between the different levels of spiritual health and its four domains.

Some researchers have argued that spiritual health consists of four domains: personal, communal, environmental and transcendental. The personal domain is defined as the relationship with oneself regarding the meaning, purpose and values in life. In this domain, the human spirit creates self-awareness in relation to selfesteem and identity. The communal domain includes the relationship between oneself and others concerning morality and culture, for instance love, justice, hope, and faith in humanity. In the environmental domain, the human relation with the environment is examined. Finally, the transcendental domain includes one's relationship with a being beyond the human level, such as $\operatorname{God}^{23}$. The findings of these studies demonstrate that the process of the formation of spiritual health comprises four domains: 1. self-consciousness (awareness of one's identity versus God, i.e., awareness of one's shortcomings and lack of awareness of the expediency of one's affairs; 2. God-consciousness (awareness of God and the divine attributes); 3. certainty (trust in God, i.e., the knowledge that God is the guarantor of human life); and 4. belonging to God (connection to God). This classification indicates that spiritual health provides guidance in the divine path.
If people are connected with God, they will enjoy a good relationship with the others and the environment. Imam Ali said, "When a person keeps his affairs in order with Allah (follows His orders sincerely), Allah will also put his affairs with others in order, and when he makes arrangement for his salvation, Allah will arrange his worldly affairs; when a person is a preacher for himself, Allah will also protect him" $\underline{24}$.

The precedents of this study have considered triple levels of spiritual health, as well as the process of realizing spiritual well-being, in all four components. The present study has also introduced the components and processes of spiritual illness in those levels.

The current study proposes future research on the relationship between the components of spiritual health that is certainty, patience, justice and jihad, across the four personal, communal, environmental, and transcendental domains.

\section{Acknowledgements}

This manuscript was extracted from the project entitled "Identification, explanation and evaluation of the knowledge components of spiritual health and its indicators based on Quranic verses and the hadiths of imams". The project was supported by Baqiyatallah University of Medical Sciences and carried out with the cooperation of the Medicine, Quran and Hadith Research Center.

\section{Conflict of Interests}

The authors declare no conflict of interests.

\section{References}

1. Moberg DO. Assessing and measuring spirituality: Confronting dilemmas of universal and particular evaluative criteria. Journal of Adult Development. 2002; 9(1): 47-60. https://doi.org/10.1023/A:1013877201375.

2. Ellison CW. Spiritual well-being: conceptualization and measurement. Journal of Psychology and Theology. 1983; 11(4):330-38. https://doi.org/10.1177/009164718301100406.

3. Woods R. What is new age spirituality. The Way. 1993; 33 : 175-88.

4. Rose S. Is the term 'spirituality' a word that everyone uses, but nobody knows what anyone means by it? Journal of Contemporary Religion. 2001; 16(2): 193-207. https://doi. org/10.1080/13537900120040663. 
5. Gomez R, Fisher JW. Domains of spiritual well-being and development and validation of the spiritual well-being questionnaire. Personality and Individual Differences. 2003; 35(8): 1975-91. https://doi.org/10.1016/S0191-8869(03)00045-X.

6. Mahmoodishan G, Alhani F, Ahmadi F, Kazemnejad A. Iranian nurses' perception of spirituality and spiritual care: A qualitative content analysis study. J Med Ethics Hist Med. 2010; 3:6.

7. Ghaderi A, Tabatabaei SM, Nedjat S, Javadi M, Larijani B. Explanatory definition of the concept of spiritual health: A qualitative study in Iran. J Med Ethics Hist Med. 2018; 11: 3 .

8. West W. Psychotherapy and Spirituality: Crossing the Line between Therapy and Religion. Canada: Sage Publications; 2000.

9. Cicirelli VG. Religious and nonreligious spirituality in relation to death acceptance or rejection. Death Stud. 2011; 35(2): 124-46. https://doi.org/10.1080/07481187.2011.5353 83. PMid: 24501832.

10. Carl Haub and Toshiko Kaneda, World Population Data Sheet, Washington, DC: Population Reference Bureau; 2012.

11. Wikipedia. Cited on 2019 March. Available from: https:// en.wikipedia.org/wiki/Hadith_of_the_two_weighty_ things.

12. Haleem MA, editor. The Quran. OUP Oxford; 2005.

13. Asadzandi M. Sound heart: spiritual nursing care model from religious viewpoint. J Relig Health. 2017; 56(6): 2063-75. https://doi.org/10.1007/s10943-015-0038-1. PMid: 25812490.

14. Asadi M, Asadzandi M, Ebadi A. Effects of spiritual care based on Ghalb Salim nursing model in reducing anxiety of patients undergoing CABG surgery. Iran J Crit Care Nurs. 2014; 7(3): 142-51.
15. Marzband R, Zakavi AA. Indicators of spiritual health based on Quran perspective. Medical Ethics Journal. 2012; 6(20): 69-99 [in Persian].

16. Braun V, Clarke V. Using thematic analysis in psychology. Qualitative Research in Psychology. 2006; 3(2): 77-101. https://doi.org/10.1191/1478088706qp063oa.

17. Kulaini S. Osul al-Kafi. Cited 2017 June; Available from:: http://lib.eshia.ir/11005/2/459 [in Arabic].

18. Chittick WC. The psalms of Islam: Muhammadi trust of Great Britain A Nothern Ireland; 2007.

19. Taheri ZS, Zandi MA, Ebadi A. The effect of spiritual care based on Ghalbe Salim Model on the sleep quality of the patients with coronary artery disease. Iran J Crit Care Nurs. 2014; 7(2): 92-101.

20. Taghizade Karati K, Asadzandi M, Tadrisi S, Abbas E. Effect of prayer on severity of patient's illness in intensive care units. Iranian Journal of Critical Care Nursing. 2011; 4(1): 1-6.

21. Esmaeili M, Fani M, Karamkhani M. The conceptual framework of spiritual health in Islamic Resources (the Quran and Nahjul-Balagha). Journal of Research on Religion and Health. 2017; 3(1): 91-101.

22. Fisher JW, Francis LJ, Johnson P. Assessing spiritual health via four domains of spiritual wellbeing: The SH4DI. Pastoral Psychology. 2000; 49(2): 133-45. https:// doi.org/10.1023/A:1004609227002.

23. Fisher JW. Spiritual Health: Its Nature and Place in the School Curriculum. Australia: Melbourne University Custom Book Centre; 1998.

24. Sharīf al-Raḍī, Muhammadibn al-Husayn, 969 or 970-1016. Nahjul Balagha = Peak of Eloquence: Sermons, Letters, and Sayings of Imam Ali Ibn Abu Talib. Bombay: Imam Foundation; 1989. 